DOI: $10.24234 /$ wisdom.v14i1.302

Igor KOLOSOV,

Konstantin SIGALOV

\title{
EPISTEMOLOGICAL FOUNDATIONS OF EARLY LEGAL UTILITARIANISM
}

\begin{abstract}
This article analyzes the aggregate of reality cognition methods used in certain theories in the history of ethics and legal thought that are based on the principle of utility. The objective of this article is to provide a full study of the methodology of the utilitarianism to determine its place in the establishment of legal utilitarianism.

The article used methods of formal logic and specific methods such as the historical method.

The main result of the article is the origins of utilitarianism is conditioned, inter alia, by the synthesis of the empirical and theoretical methodology. Heretofore, the application of purely empirical or purely theoretical methodologies for considering the state and legal phenomena through the prism of utility did not lead to the creation of branch of philosophy, economic or legal thought - utilitarianism.

The main conclusion of this article is that the "moral arithmetic" created under classical utilitarianism and later developed in the contemporary utilitarianism, based on which it is possible to compute the utility of this or that action (the totality of actions), contradicts such universal legal values as justice, defence, enforcement of rights and freedoms, the principle of equality, and the moral values, and, therefore, cannot be supported.
\end{abstract}

Keywords: utilitarianism, utility, legal utilitarianism, methodology, epistemology, legal philosophy, empiricism, rationalism, consequentialism.

Introduction

In his work "An Introduction to the Principles of Morals and Legislation", J. Bentham notes, that human actions are underlaid by pleasure and pain. They determine human behaviour: what a person actually does, what he/she aspires to do, and what he/she should do. This is why influencing a person means, in the long run, influencing his / her feelings to cause pleasure or pain. This is the stimulus and the motive driving the action. This is the explanation for human behaviour. According to J. Bentham (2000), a per- son wishes to achieve happiness and to avoid pain, even though he/she is not always aware of that (p. 14). These contemplations generate a methodology (what and how to do) for the performance of moral action in utilitarianism. The main idea of the method is the calculation of the actions performed by an individual. Thus, performing an action or facing a situation he/she recognizes as morally significant, the individual calculates who would be influenced by the action and how much pleasure or pain it could cause to those exposed to it, and chooses the type of action to optimize this amount of pleasure or pain. 
Optimum is the maximum happiness caused to the maximum number of people exposed to the situation, and (or) minimization of pain to the maximum number of individuals. This way, any choice is determined with the relative level of total utility of its consequences or results. In this situation, the degree of happiness is the entire totality of pain and pleasure that this or that action, motive or institution may cause to this or that number of individuals. This approach suggests that happiness should be measurable, therefore, justifying the "moral arithmetic" of J. Bentham. In particular, J. Bentham suggested measuring it by the intensiveness of pleasure, its duration, considering the possibility of its occurrence and the period of time after which it will occur. There should be a preference of pleasure that is intensive, long-lasting, and likely to occur in the nearest time. If the decision adopted concerns the interests of more than one individual, but a group (society), for example, in law-making, the list of quantitative criteria is replenished with one more criterion: the spread of pleasure. In that case, to determine the "general tendency" of an action, it is required to:

a) sum up the figures expressing the domination of pleasure over pain for those who benefit from the action;

b) sum up the figures expressing the domination of pain over pleasure for those who do not benefit from the action;

c) draw the total balance.

Such summing up may not only reveal the positive or negative tendency of the action but also help select the potential behaviour strategy (introduced legal regulation or any other legally relevant action) yielding maximum happiness for the maximum number of people. The principal condition of the correctness of such utilitarian calculation is the conservation of equal value of happiness for each person to determine the moral correctness or incorrectness of the action performed.

Summing up the utilities is quite important in a legal activity in legal utilitarianism. This way, a lawmaker deciding to enact this or that law must as per the legal utilitarianism, consider the way these legal regulations may influence the pleasure or pain of the persons bound by such legal regulation. In adopting a decision within the framework of behaviour permitted by law, or adopting a decision to break the law, the law enforcer must, as per the legal utilitarianism, consider the utility of all possible options (including the opportunity costs).

This opportunity of summing pleasures and pain, making grounded, politically or legally relevant decisions, ensuring the adequacy of this or that decision or justifying an unpopular decision appeared attractive to the public officials.

The legal utilitarianism had a significant impact on the 19th-century legislation, especially in England. For instance, under the influence of the ideas of J. Bentham, several strict legal regulations were abolished in England in the early 19th century (Bedau, 1983, p. 1036). The legal utilitarianism had a special impact on criminal law theory and criminal legislation, including the current one (Hart \& Sacks, 1958, pp. 113-114). Utilitarianism strongly influenced civil law, particularly the tort and contract law (Terry, 1915, p. 40; Fuller, 1941, p. 799). According to J.B. Ames (1908), "The law is utilitarian. It exists for the realization of the reasonable needs of the community. If the interest of an individual runs counter to the chief object of the law, it must be sacrificed" (pp. 97, 110).

This question interests scientists in a similar way. Various works analyze legal utilitarianism. Some of them cover the questions of the ideolo- 
gy used in the legal utilitarianism.

Among such works, it is worthwhile mentioning "Legal Utilitarianism" by Richard F. Bernstein (1979), which pays special attention to the contemporary concept of act utilitarianism and its application in the legal activity, including judicature (pp. 127-146). In addition, the questions of legal liability and the rule of law are considered.

Apart from that, special attention should be paid to the article by R. Posner "Utilitarianism, Economics, and Legal Theory" (1979), where he introduced his original theory of law - the concept of wealth maximization (pp. 103-140). Related to the topic of the present article, in the designated study, the justification of the difference between the positive and normative analysis and establishment of a preference criterion between ethic theories has an important place. An article by E. Weinrib "Utilitarianism, Economics, and Legal Theory" (1980), also makes a significant contribution into the development of the legal utilitarianism, continuing the studies of the above-mentioned questions and carrying out a critical analysis of the work written by R. Posner (pp. 307-332).

It is also worthwhile noticing the academic degree thesis "Bentham's Study of Law" by A. N. Ostroukh (2002), where, in paragraph 2.2, the principle of utility by J. Bentham and its place in the legal theory are described. In addition, the mentioned study elaborates the issues of the methodology used by J. Bentham (paragraph 2.1), justifies its theoretical nature (rationalism), and considers the utilitarianism of J. Bentham by analyzing his vision of certain branches of law in Chapters 3 and 4 of the research.

Legal regulation determines the borders of human behaviour (the regulatory function of law). What are those borders in the historical ret- rospective, considering that man is a biosocial creature, i.e. living in the society man has biological and social needs, the satisfaction of which may not always coincide with the interests of the other people living in this society, or even interfere with the freedom of others? Since at its core, utilitarianism is an ethic theory, it may within its own subject, and methodological apparatus provide some answers to the set questions from its own perspective and suggest (present a concept) a matching method of legal regulation. This explains the interest of public officials and scientists to this theory.

In continuation of the issues raised by the above works (theoretical aspect), and in order to evaluate the application of the relevant utilitarian theories (practical aspect), the contribution of this article to science is that a detailed analysis of the utilitarian legal methodology is aimed not only at expanding knowledge of the methodology used, but also to create the basis for further research in this direction, which will be based on a more complete understanding of the methodology.

Analysis of social relations through the legal utilitarianism may help to find some legal solutions to maximize the utility. However, is such an approach applicable to law-making and law enforcement? How valid is it in the legal activity? All of these can be found out by analyzing the methodology of the legal utilitarianism. This is the research goal of this article and, therefore, the empirical and theoretical methodology of the legal utilitarianism attracts great attention.

$$
\begin{gathered}
\text { The Empirical Methodology of } \\
\text { the Legal Utilitarianism }
\end{gathered}
$$

One of the major thinkers developing the theory of cognition based on the empirical methodology, J. Locke (1836), remarks that all ideas 
originate from perception and reflection. "Let us then suppose the mind to be, as we say, a white paper, void of all characters without any ideas ["white paper" - "tabula rasa" - remark by the authors]; how comes it to be furnished? To this, I answer in one word, From Experience: In that, all our Knowledge is founded, and from that, it ultimately derives itself. Our Observation employ'd either about external, sensible Objects; or about the internal Operations of our Minds, perceived and reflected on by ourselves, is that, which supplies our Understandings with all the materials of thinking. These two are the Fountains of Knowledge, from whence all the Ideas we have, or can naturally have, do spring" ( $p$. 51).

Based on that, we suppose that as "tabula rasa", a person may cognize the social relations regulated by the law through perception and reflection, entering these social relations and observing them. Later, a specially authorized subject, the lawmaker, and the persons bearing the right to the legislative initiative may come up with the optimal mechanism of legal regulation. Working to satisfy the requirements of the lawmaker expressed in laws, the law enforcer, cognizing the social relations through his perception, may maximize the utility of the applied legal regulations. The realization of the right (enforcement, execution, application, utilization) as a regulator of social relations is directly linked to the empirical cognition of law due to the assessment of such relations through sensual methods. This way, the empirical cognition of law serves as a basis for the acquisition of knowledge of the law.

However, if the law is created by people in the rule-making process, the question appears: how can it be created for the legal regulations to be the most efficient, as empirically we are not able to cognize an object or a phenomenon that does not yet exist, that has not been created? In answering this question from the point of view of sensualism, it is important to note that social relations between people develop regardless of whether they are regulated by law or not. Legal regulation is not a compulsory condition for social relations; they may be regulated with any other methods, like morals, other regulators, or be unregulated at all. Moreover, in the modern world, there are many social relations not regulated by any law. However, along with that, when entering certain social relations, the subjects of law acquire knowledge of these relations based on the empirical perception, and may, therefore, create mechanisms (including legal ones) to bring these social relations to order, creating, therefore, some legal regulations. It appears like the utility of this or that way of regulating social relations, and legal regulation efficiency may also be assessed based on the same concept, relying exclusively upon the empirical cognition of the legal regulation, or cognizing the method of regulation of the social relations as it is applied to similar social relations. Therefore, empirical cognition helps revealing, for example, the inefficiency of applying a method for the regulation of social relations and the need to bring the current legislation to realize the need for the introduction of changes to the existing legal regulation mechanism.

The legal utilitarianism was developed generally in the second half of the 18th century, associated, primarily, with the works by J. Bentham and J. S. Mill. Classical utilitarianism chronologically appears after the natural law and social contract theories; due to the similarity of the used methodology, it may be concluded that to a certain extent it is a consequence of the natural law and social contract theories. Utilitarianism was largely in line with the ideology and the so- 
cial relations of that time. The works of utilitarian philosophers have made a great impact on the development of liberal and legal ideology and the legal regulation mechanism.

But together with that, to our mind, long before the emergence of classical utilitarianism there appeared a lot of ethics and legal ideas, which may hardly be referred to the legal utilitarianism, but they set the prerequisites and methodological base for their genesis. To determine the methodological foundation of classical utilitarianism, it appears reasonable to consider the ideas of applying the principle of utility to lawmaking and law enforcement activity before J. Bentham.

In antiquity, the Epicureans, Stoics, Democritus and Aristotle raised the questions of the theory of cognition linked to the principle of utility. For instance, Epicureanism based on maximization happiness, but defines happiness more as a state of tranquillity than pleasure. Egoist theories hold that an action is morally right if it maximizes the good for oneself (Evans, 2004, pp. 407-424). In addition, Aristotle remarks that true cognition is hard because the essence of the cognition object is hidden. There are things and phenomena more knowable and clear to us, and those that are clearer and more knowable by nature. The first ones present the world given to us in sense-perception; the second ones present the essence of being and reasons (forms) of separate things, their causes and origins. The latter are "the universals" that are "more obscure" for human cognition, for being further from sense-perception (Aristotle, 1991, pp. 3-5). However, based on empirical perception, they may be cognized through the activity of thought.

Based on the indicated concept of knowledge of Aristotle, it may be remarked that in legal activity the "clearer" phenomena may be, for instance, some certain social relations existing in the society, while the latter "universals" may be the essence of law, i.e. the nature and purpose of legal regulation of such social relations, as well as the primary causes for introduction of this or that legal regulation of the social relations. Considering the current understanding of "utility", which is defined as an ability of an economic commodity to satisfy one or several human needs (Kapteyn, 1985, pp. 1-2), the studies of Plato and Aristotle reveal the origins of applying the principle of utility to studying the origin and development of law and state based on the empirical methods of activity cognition.

Contemplating on the just city-state, Plato (2018) remarks, "A state, I said, arises, as I conceive, out of the needs of mankind; no one is self-sufficing, but all of us have many wants. [...]. As we have many wants, and many persons are needed to supply them, one takes a helper for one purpose and another for another; and when these partners and helper are gathered together in one habitation the body of inhabitants is termed a State" (p. 226). Speaking of the utilitarian component of these ideas, it is worthwhile noticing that Plato speaks of pleasure as a replenishment, and so, to a certain extent, does Aristotle. In other words, certain commodities and actions of people may be deemed useful for the replenishment of a deficit of resources or unsatisfied needs. It is also accompanied by the achievement of pleasure. Thus, pain is a deficiency of the natural state, and pleasure is its replenishment (Aristotle, 1906, p. 323). According to Plato, replenishment must be provided when laws are enacted. For instance, in The Laws of Plato (1921) the philosopher, relying upon his observations, perception and reflection, remarks, that "laws which are not established for the good of the whole state are bogus laws" (p. 129). Considering the 
above, as well as other postulates of "Laws", we may conclude, that in the opinion of Plato, legal regulation must ensure the replenishment of deficits for a better life of some people and the society as a whole, provide the satisfaction of their needs, make the state and its citizens "happy and satisfied". In other words, for Plato, laws must be useful.

Also relying upon empirical cognition, Democritus remarks, "The law seeks to give seemly form to the lives of men [...] for only to those who obey it does it reveal its full and peculiar excellence" (Hamburger, 1969, p. 17). Considering this, we suppose that, for Democritus, to achieve the common good, people need to obey the law. And since, according to Democritus, people are willing to achieve happiness and the good (Vitz, 1979, p. 145) (and the pleasure may or may not be (Vitz, 1979, p. 146) the source of happiness), the obedience to law may bring people (and the society as a whole) closer to the common good.

The analysis of works by antique philosophers and thinkers brings us to a conclusion on the presence of certain ideas close to classical utilitarianism; at that, developing their ideas, the thinkers rely upon sense-perception of the reality. Thus, the famous Russian philosopher of law, I. V. Mikhaylovsky (1914), in his "Essays on the Philosophy of Law" writes: "the considered branch of ethics [utilitarianism - remark by the authors] is quite old: it existed back in Greek philosophy; there is an opinion that Aristotle himself was a utilitarianist" (p. 30).

In the modern period, there appeared a constellation of researchers who continued the logical development of ideas on the sense-perception of the objectively existing reality. F. Bacon made the greatest influence on the establishment of empiricism. His works are based on the inductive methodology of scientific research led to the emergence the Baconian method. This method is based on acquiring knowledge from the surrounding world through experiment, observation and hypothesis testing. The research method developed by F. Bacon is an early predecessor of the scientific method. It was described in his work titled "Novum Organum" by F. Bacon as a replacement of methods once presented in "Organum" by Aristotle.

F. Bacon claims that the objective of scientific cognition is not observing nature as it was in antiquity or cognition of God as in medieval philosophy, but the benefit and utility for the humankind. Science is the means, not the end. Man is the master of nature. That is the leitmotiv of the philosophy of F. Bacon. The activist utilitarianism of F. Bacon means that with the emergence of man, nature decomposes into subject and object, which are at the same time separated and connected through instrumental activity.

F. Bacon orients science towards seeking truth not in books, but in practical activity, in the immediate observation and studies of nature and society. His philosophy may be understood as a revival of the antique natural philosophy with the entire philosophical system of nature set in the centre. Therefore, the central problem of the philosophy of F. Bacon is the problem of relations between man and nature. This problem was resolved in line with utilitarianism; therefore, it can be said that he laid the origin of utilitarian methodology, which later also developed in the philosophy of pragmatism.

Activist utilitarianism of F. Bacon, based on the empirical cognition of the reality and his vision of the law, is being widely spread. Thus, F. Bacon considered the law to be grounded upon justice and social benefit. They act as not only the sources of law but also the criteria for law 
assessment. The philosopher remarks that "in Civil Society, either law or force prevails" (Bacon, 2011, p. 88), while violence, intentional cunning and cruelty of law generate injustice. F. Bacon comes to the conclusion that to achieve the common goal, and it is necessary to "extract a symbol and an idea of fairness" in every sphere of law to "assess the properties of laws of this or that state and attempt to correct them". In his studies of law, F. Bacon was striving to overcome the dualism of the natural and positive law in favour of the positive law (law of the state), to merge and express the requirements of both natural justice and real policy of the state in law (positive law). The main requirements a good (fair) law must satisfy to ensure the achievement of the common good, are, for F. Bacon (2011), the following: "that law may be set down as good, which is certain in meaning, just in precept, convenient in execution, agreeable to the form of government, and productive of virtue in those that live under it" (pp. 89-90).

In the legal utilitarianism, a special place is occupied by the work of J. S. Mill, one of the founders of utilitarianism. Considering the methodology used in the legal utilitarianism, J. S. Mill developed five methods (canons) of causal relations between objects and phenomena discovered by various researchers: method of similarity (agreement) - J. Scotus, method of difference W. Ockham, method of concomitant variations (degrees) - F. Bacon, method of residuals - J. Herschel, joint method of agreement and difference (synthesis of two methods) first described by J. S. Mill himself. Then the said methods were synthesized by J. S. Mill in his research "System of Logic, Ratiocinative and Inductive". Having established the main canons of empirical cognition, J. S. Mill used them as methodology when developing his ethics and legal study based on the utilitarian postulates.

J. S. Mill denied the idea of the politics capable of giving normative recommendations to all societies regardless of their national character and degree of development of public relations. This formed the basis for J. S. Mill's study in the way we know it now, and the utilitarianism, which, unlike the utilitarianism of J. Bentham, cannot provide any certain practical recommendations on the government structure and the legal regulation system.

Utilitarianism of J. S. Mill is based on understanding social processes through the aggregated characteristics of the social agents themselves, just like the social nominalism. Individuals are regarded as "social atoms" creating a sum of certain properties, making up an integral metaquality that is sociality as such. For utilitarianism of J. S. Mill, being a product of empirically oriented thought, this motivation is especially typical. This way, to extract the laws of social development, to formulate the grounds for the behavior of certain individuals, social groups and the society as a whole, it is necessary to appeal to the motivation of a single element of society, which is a person. Once the motivation is found, it needs to be extrapolated to the aggregate of other individuals, bringing up a new social property. For the utilitarian philosophers, such protoprinciple, unified for the sociality and the person as an individual, is the principle of utility.

Based on everything stated above, we may conclude that a subject will be guided with the principle of minimizing negative consequences and maximizing positive consequences for himself in any situation. In other words, an individual is always guided and motivated by what brings utility to him. In this regard, utilitarianism, being a product of empiricism, claims that no matter how thoroughly we study a subject, it is impossi- 
ble to discover any other activity besides that based on the principle of maximizing utility.

Therefore, it appears important to highlight, that regardless of the research object, due to the presence of sense-perception, the empiricismbased methodology of research, such as methods of observation, experiment and follow-up processing of the results with the theoretical methods, when used correctly, will lead new knowledge. In terms of practical jurisprudence, the above methodology can be used to improvement of the legislation. For example, we see it necessary to monitor (i.e. to observe) the law enforcement practice to detect gaps and inefficient legal regulations in the legislation, which may lead to a decrease in the overall public well-being. Before the introduction of such measures, to determine their efficiency and forecast the enforcement problems, in some situations, it appears reasonable to start a legal experiment.

We assume that, regarding utilitarianism, the empirical cognition methods allowed, first of all, to establish the main provisions of the theory, and, secondly, to ensure its further development. It is explained by the fact that such categories as "utility", "common good" and some others are largely subjective, as expressed in the way they are evaluated by individuals, social groups, and the society as a whole. Therefore, cognition and comprehension of utilitarianism are possible when relied upon the empirical methods of research.

Apart from that, the methodology of legal utilitarianism cannot be limited to empirical cognition alone. Despite the confrontation of the empirical and theoretical methods of cognizing reality, the opposition of induction and deduction, cognition of law cannot be of pure empirical nature. Empirical knowledge is not complete, as all it provides is the idea of the external properties of the studied object. Only theoretical cognition can help recognize the essence of the subject, determine its internal properties and causes. Moreover, senses can be confusing; they cannot provide a tool for revealing patterns and drawing conclusions (which is especially important for the macro-level decision-making), and, therefore, such cognition of reality cannot be comprehensive; it means that the methodology of legal utilitarianism must be not of purely empirical, but also of theoretical nature.

\section{The Theoretical Methodology of the Legal Utilitarianism}

The thesis of R. Descartes, presented in his "Principles of Philosophy": "Cogito, ergo sum" was the beginning of rationalism, which presents a methodology or a theory "in which the criterion of truth is not sensory but intellectual and deductive" (Bourke, 1962, p. 263) as a basis. Besides, rationalism operates such forms of cognition as concept, judgment and logical consequence.

Just like in empiricism, which recognized sense-perception methods of cognition even before F. Bacon, in rationalism, some cases of operating such forms of cognition as a notion, judgment, and statement of reasons had also occurred before R. Descartes.

To be more precise, it happened in Ancient India. The name of the political and legal treatise of Arthashastra is commonly translated from Sanskrit as "the science of politics". However, besides the literal translation, the name of the treatise is "the science of benefit" or "guide to achieving utility" ("the science of politics" in Sanskrit would sound as "Nitishastra") (Kangle, 2010; Kosambi, 1977, p. 141).

The highlighted need for operating the principle of utility, one of the utilitarianism compo- 
nents, is found not only in the title but in the text of the treatise as well. For instance, Arthashastra gives the state governors some practical recommendations on administration based on three equal values, factors (being the dominating ones not only for statecraft but also for the daily life of citizens): charity (or law, religion), wealth (or utility), desire (or pleasure, love) (Kautilya, 2016, Book I, Chapter 7, Paragraph 3). At the same time, Kautilya, the author of Arthashastra, gives his preferences to wealth: "Kautilya holds that wealth and wealth alone is important, inasmuch as charity and desire depend upon wealth for their realization" (Kautilya, 2016, Book I, Chapter 7, Paragraph 4).

The methodological basis for Arthashastra treatise is the permanence of subject, i.e. statecraft, and the unchangeability of human nature and the motives of human behaviour. Based on that, the treatise actually operates the method of historical analogies and examples, which is a constituent part of the rational cognition of reality.

It makes it possible to draw a parallel between the foundation and methodology of Arthashastra and utilitarianism of J. Bentham. Thus, for the latter, it is not only empiricism but also rationalism and epistemological optimism that are intrinsic. Logical contemplations underly both Arthashastra and utilitarianism of J. Bentham. At the same time, an emphasis on review of the established social values, such as legal values, partial rejection (for Arthashastra) and reproach (for the utilitarianism of J. Bentham) for the religious superstitions and moral prejudice are also typical.

The main factor for the political and legal issues for Arthashastra and the utilitarianism of $\mathrm{J}$. Bentham is not a traditional (customary), but rationalistic view. However, rationalism (as a branch of philosophy, it appeared much later), or rationalist component (the latter more applicable to Arthashastra) is still limited. It is limited, at least, with the boundaries of empiricism.

Later, in modern history, the ideas of using theoretical methodology under the legal utilitarianism were also found in the works by B. de Spinoza. According to Spinoza, one of the main ways of acquiring knowledge is finding reasons based on consequences, or deduction of the essence of a thing from a general notion. This way of cognition, though scientific, does not provide a truthful, strictly required knowledge adequate to the object, as the properties of the thing are not perceived directly through its essence. Another method of cognition, known as the main one, is the perception of a thing exclusively through its essence. This means of cognition referred to by B. Spinoza as intuitive, provides, as per his theory, an infallible knowledge, corresponding strictly to the essence of the thing. For B. Spinoza, intuition is not a mystical category; it means rationalistic cognition of the essence of things based on the cognition of the essence of a substance. Despite the seemingly abstract nature of B. Spinoza's reasons of substance, attributes and modus, his philosophy is distinctively practiceoriented and applicable, inter alia, to the analysis of state and legal phenomena.

Thus, according to his vision, the increment of social good is possible through law-making and enactment of the right laws. And at all that, since people have their own needs, there is an urge for a law to ensure that the satisfaction of those needs does not harm other persons. Particularly, B. Spinoza (1891) remarks: "if men were so constituted by nature that they desired nothing but what is designated by true reason, society would obviously have no need of laws: it would be sufficient to inculcate true moral doctrines; 
and men would freely, without hesitation, act in accordance with their true interests. But human nature is framed in a different fashion: everyone, indeed, seeks his own interest" (p. 74). Therefore, the laws enforced through pressure from the state shall act as a deterrent factor, restraining crime and offence, that would increase the utility for the lawbreaker to the detriment of the utility for other persons and (or) the common good.

Later, in the classical utilitarianism, the theoretical methods were used along with the empirical ones. At that, the methodology of the natural law school which appeared in modern history, before the classical utilitarianism was established, is also not based on the empirical process alone (such as J. Locke), but also on the theoretical process of cognition. Thus, A. M. Mikhaylov (2019) remarks the presence of "mathematical rationalism of the natural legal philosophy" (p. 203), particularly, in the works by Christian von Wolff, where the natural law system is built deductively, as a logically complete chain of axioms, arguments and consequences ("mos mathematicus"), with a geometrical precision developing the comprehensive system of the natural law (Anners, 1996, p. 227). J. A. Schumpeter (2006) remarks that "in approach, in methodology, and in the nature of its results utilitarianism actually was another, the last, natural-law system" (p. 128). Remarkably, similar to the way Chr. von Wolff developed natural legal philosophy with the mathematical methods of rationalism on the basis of "De Jure Belli ac Pacis" by H. Grotius, the late 19th-century marginalism, using the mathematical apparatus, on the basis of utilitarianism becomes a theory which made it possible to calculate and compare the utility, including the social ones, and, particularly, legal regulation. The utilitarian origins of marginalism ground from the thoughts of L. Walras (1965), who wrote that agents to "attain maximum satisfaction" (p. 125), W. S. Jevons (1871) - “economy as a calculus of pleasure and pain" (p. vii) and F. Y. Edgeworth (1881) - "principles of greatest happiness, utilitarian or egoistic constitute the first principles of ethics and economics" (p. v).

In "Essay on Bentham" by J. S. Mill remarked the theoretical methodology in the framework of the legal utilitarianism of J. Bentham. For instance, J. S. Mill writes, that J. Bentham has an inclination to analysis and synthesis. "He began de novo, laid his own foundations deeply and firmly, built up his own structure, and bade mankind compare the two; it was when he had solved the problem himself, or thought he had done so, that he declared all other solutions to be erroneous" (Mill, 1985, p. 82), characterizing, therefore, the legal utilitarianism of J. Bentham as synthetic, and, in this regard, second to none. After all, the "moral arithmetic" of J. Bentham, "mathematizing" the analysis of possible results of the action and suggesting the decisions to be taken on the basis of continuous comparison of quantitative properties of pleasure and pain, are based on the theoretical methods of cognizing reality.

To maximize the utility, J. Bentham comes up with the idea to create "Pannomion", which, according to his ideas, may ensure maximization of the common good (common utility). "Pannomion" is supposed to present a collection of laws which, according to J. Bentham, should not contain a large number of certain rules for a law enforcer, which would not leave space for following the principle of utility directly when the essence of social relations does not require any compulsory imperative regulation. "Pannomion" should more likely to be a set of "a somewhat small numbers of quite general rules broadly de- 
fined" (Postema, 1986, p. 430). That requires to determine a rational, comprehensive method, that would allow the systematic establishment of the laws conforming to the principle of utility. Given the diversity of social relations and invariance of life situations, such method must be rather be based not on the need to foresee and regulate all possible actions of the subjects of law with an enormous number of quite precise rules not leaving any questions to be resolved at the discretion of the law enforcers including the court, but be oriented on more general regulation with few legal provisions (Postema, 1986, p. 422), if those are not the most significant social relations, which will also facilitate stability of legal regulation.

That explains the difference in utilitarian ideas in the applied methodological approach. Both J. S. Mill and his opponents spoke of the contradictions between them as an argument between the two opposite schools of thought: intuitive (sensual, empirical) and inductive (rational) approaches. This is vividly manifested in the answers of J. S. Mill to the opinions of H. Sidgwick and W. Whewell, two of his most remarkable opponents, to the main claim against utilitarianism, that it neglects the internal dictate of the conscience. The reaction of J. S. Mill to the statements made by $\mathrm{W}$. Whewell in this regard in 1852, literally repeat the answer of J. S. Mill to H. Sidgwick in 1835. Thus, he remarks that even though both parties of the argument recognize the presence of moral feelings and conscience, "there are two theories considering the origin of these phenomena, which have been dividing philosophers since the earliest ages of philosophy" (Mill, 1961-91, pp. 51, 172). J. S. Mill (2001) again turns to this dichotomy in his "Utilitarianism": "According to the one opinion, the principles of morals are evident a priori, requiring no- thing to command assent, except that the meaning of the terms is understood. According to the other doctrine, right and wrong, as well as truth and falsehood, are questions of observation and experience" (pp. 6-7).

In epistemology, the question of the source of true knowledge remains relevant. As the man perceives the world through the senses and mind, it appears right to find out what the construction of knowledge starts from, from the sensual impressions or the work of the mind. Along with that, empirical and theoretical knowledge are two types of reflecting the reality, inextricably intertwined, characterizing the integrated process of cognition. The generation of senses has a rational component, while in thinking, it is possible to find some sensual, emotional, empirical content. The sensual stage reflects phenomena. The rational reveals the essence of things, facilitates comprehension of the underlying laws of their existence. Based on the above and under the legal utilitarianism, it is considered reasonable to assert an ambivalent nature of the applied methodology. For the legal utilitarianism, both empirical ad theoretical methods of cognizing reality in their interaction are intrinsic.

\section{Conclusion and Results}

In view of various ethics and legal studies, based on or using the principle of utility, it appears necessary to remark that the principle of utility is connected to the methodology. Thus, the philosophic outlook of Aristotle, Plato, Democritus, and, later, some works written in modern history, are based on the empirical methodology. Rationalism begins to manifest itself in the works applying the principle of utility written in modern history. Nevertheless, some rationalism components appear earlier. At the same time, 
basically, the rationalistic trend related to the principle of utility appears only in the works by B. Spinoza, C. Beccaria, J. Bentham.

Before J. Bentham, the ethics and legal concepts of utilitarianism mostly appealed to empiricism as the preferred methodology. The rationalism of B. Spinoza doubtlessly made a great impact on the development of philosophy, but it cannot be completely included into the ethics and legal concept of utilitarianism since he did not develop any cohesive ethics and legal concept based on the principle of utility.

The main contribution into the theoretical development of applying the principle of utility to the state and legal phenomena was made by representatives of classical utilitarianism, J. Bentham and J. S. Mill. Along with that, further development of the methodology for making legally and politically relevant decisions in the framework of the legal utilitarianism generated a need for summing up the utility from the performance of different actions to maximize the utility of such decision, as was also expressed in the "moral arithmetic" by J. Bentham, which, in its turn, contradicts the moral intuitions.

Let us suppose that someone has such a developed sense of pleasure that he gets twice as much pleasure of a certain amount of monetary units (or any other measurable commodity) as another person experiencing less satisfaction of material commodities. Can it be taken as a reason to redistribute the commodities from the second person to the first? It would make a larger increment of utility for the first person than the decrease of utility for the second; therefore, as per this logic, the aggregate utility would increase. A utilitarian philosopher is likely to give a positive answer to this question. Similarly, the legal utilitarianism may excuse crimes and other offences if the "pleasure" of the lawbreaker ex- ceeds the "pain" of the victim, or if the first can compensate the caused damage in a way that makes a positive impact on the utility function of the victim (compared to the moment before the offence). In this regard, the total utility has increased, such an offence would not be considered as socially dangerous from the perspective of utilitarianism, or it may be even found to be socially preferable for it was oriented at the increment of overall utility. Consequently, as the legal utilitarianism claims that this should be the fundamental principle of the legal policy, it would encourage an offender because his wrongful behaviour maximizes his and total happiness. As utilitarianism postulates, the achievement of happiness by one individual in a society is a contribution to the achievement of the whole society's overall happiness. This fact is the "dark side" of one of the utilitarianism properties: its tolerance to various concepts of good. The legal utilitarianism is so individualistic in its prerequisites that it gives the same "status" to criminals enjoying committing offences on one side, and to heroic police officers, firefighters or a brilliant engineer on the other.

To our mind, this side of the utilitarianism concept should not be supported, and, therefore, such theory premises should not underlie the development of legal policy. Supporting this property of utilitarianism, we would behave like a "happy pig" J. S. Mill had been warning us against. This side of the legal utilitarianism contradicts both the general legal values, such as justice, defence, and provision of rights and freedoms, the principle of equality, and the moral values.

At the same time, adherence to the universal principle of equality is supposed to make a disciplinary effect on all spheres of social relations and to act as an underlying criterion for the as- 
sessment of legal regulation of not only rights and freedoms provided by law, but also of the rights acquired on the basis of law; compliance with the principle, guaranteeing protection from any form of discrimination in the exercise of rights and freedoms, forbids, inter alia, to introduce such difference in the rights of people belonging to the same category. We may suggest, therefore, that maximization of utility cannot act as such an excuse, for it creates inequality not due to any objective socially relevant factors, but due to a certain elasticity of utility functions of a certain individual.

\section{REFERENCES}

Ames, J. B. (1908). Law and Morals. Harvard Law Review, 22(2), 97-113. doi: $10.2307 / 1324144$.

Anners, E. (1996). Istoriya yevropeiskogo prava (History of European Law, in Russian). Moscow: Nauka.

Aristotle (1906). The Nicomachean Ethics. (F.H. Peters, Trans.). London: Kegan Paul, Trench, Trubner \& Co.

Aristotle (1991). Complete Works. Vol 1. Physics. Princeton, N.J.: Princeton University Press.

Bacon, F. (2011). The Works of Francis Bacon. Vol. 5: Translations of the Philosophical Works. New York: Cambridge University Press.

Bedau, H. (1983). Bentham's Utilitarian Critique of the Death Penalty. The Journal of Criminal Law and Criminology, 74(3), 1033-1065. doi: 10.2307/1143143.

Bentham, J. (2000). An Introduction to the Principles of Morals and Legislation Jeremy Bentham. Kitchener: Batoche Books.
Bernstein, R. F. (1979). Legal Utilitarianism. Ethics, 89(2), 127-146. doi: 10.1086/292092.

Bourke, V. J. (1962). Rationalism, in Dictionary of Philosophy (D. D. Runes, Ed.). Totowa, NJ: Littlefield, Adams and Company.

Edgeworth, F. Y. (1881). Mathematical Psychics. An Essay on the Application of Mathematics to the Moral Sciences. London: Kegan Paul \& Co.

Evans, M (2004). Can Epicureans Be Friends? Ancient Philosophy, 24(2), 407-424. doi.:10.5840/ancientphip200424250.

Fuller, L. L. (1941). Consideration and Form. Columbia Law Review, 41(5), 799-824. doi: 10.2307/1117840.

Hamburger, M. (1969). The Awakening of Western Legal Thought. New York: Biblo \& Tannen Publishers.

Hart, H. M., \& Sacks, A. (1958). The Legal Process: Basic Problems in the Making and Application of Law. Cambridge, Massachusetts.

Jevons, W. S. (1871). The Theory of Political Economy. London: Macmillan.

Kangle, R. P. (2010). The Kautiliya Arthasastra (2nd ed.). Delhi: Motilal Banarsidass.

Kapteyn, A. J. (1985). Utility and Economics. De Economist, 133(1), 1-20. doi: 10.1007/BF01675959.

Kautilya (2016). The Arthashastra. Create Space Independent Platform. California: Scotts Valley.

Kosambi, D. D. (1977). The Culture and Civilization of Ancient India. New Delhi: Vikas Publishing House.

Locke, J. (1836). An Essay Concerning Human Understanding. London: T. Tegg and Son. 
Mikhaylov, A. M. (2019). Sravnitel'noye pravovedeniye: dogma romano-germanskogo prava (Comparative Law: Dogma of Romano-German Law, in Russian). Moscow: Izdatel'stvo Yurayt.

Mikhaylovsky, I. V. (1914). Ocherki filosofii prava (Essays on the Philosophy of Law, in Russian). (Vol. 1). Tomsk: Izdanie knizhnogo magazina Posokhina V. M.

Mill, J. S. (1961-91). The Collected Works of John Stuart Mill. (J. Robson, Ed.). Toronto: University of Toronto Press.

Mill, J. S. (1985). The Collected Works, Vol. XEssays on Ethics, Religion and Society (J. M. Robson, Ed.). Toronto: University of Toronto Press; London: Routledge and Kegan Paul.

Mill, J. S. (2001). Utilitarianism. Kitchener: Batoche Books.

Ostroukh, A. N. (2002). Uchenie Bentama o prave (Bentham's Doctrine of Law, in Russian). $\mathrm{PhD}$ thesis. Moscow.

Plato (1921). The Laws of Plato (E. B. England, \& D. Litt, Eds. and Intrd.). (Vol. 1, Books I-IV). Manchester, at the University Press; Longmans, Green \& Co. London, New York, Bombay, etc.

Plato (2018). The Republic (The Republic of Pla- to). Wildside Press LLC.

Posner, R. (1979). Utilitarianism, Economics, and Legal Theory. The Journal of Legal Studies, 8(1), 103-140. doi: 10.1086/467603.

Postema, G. J. (1986). Bentham and the Common Law Tradition. Oxford: Clarendon Press.

Schumpeter, J. A. (2006). History of Economic Analysis. (E. B. Schumpeter, Ed.; M. Perlman, Intrd.). Routledge. The Taylor \& Francis e-Library.

Spinoza, B. (1891). The Chief Works of Benedict de Spinoza. (R.H.M. Elwes, Trans. and Intrd). (Vol. I). London: George Bell and Sons.

Terry, H. T. (1915). Negligence. Harvard Law Review, 29(1), 40-54. doi: $10.2307 / 1325735$.

Vitz, B. B. (1979). Demokrit (Democritus, in Russian). Moscow: Mysl'.

Walras, L. (1965). Elements of Pure Economics. (W. Jaffe, Trans.). London: George Allen and Unwin.

Weinrib, E. (1980). Utilitarianism, Economics, and Legal Theory. The University of Toronto Law Journal, 30(3), 307-332. doi: $10.2307 / 825489$. 